\title{
The effect of pinealectomy on oxygen consumption and rectal temperature of adult hens
}

\author{
M. Pietras \\ Department of Feed Science and Animal Products, \\ Research Institute of Animal Production \\ 32-083 Balice, Poland \\ (Received 12 February 1996; accepted 9 July 1996)
}

\begin{abstract}
The study was conducted on fifteen 16-month Leghorn hens raised in cages under standard feeding conditions and lighting 14L:10D (light from 7.00 to 21.00 ). The control group comprised hens that did not undergo any procedure, the second control group underwent a mock operation, while the experimental group was subjected to pinealectomy. The procedures were carried out under general anesthesia. Oxygen consumption was measured and rectal temperature recorded during the light $(10.00-15.00 \mathrm{~h})$ and dark (22.00 $-3.00 \mathrm{~h})$ periods of the day. Feed intake was recorded for the periods between 7.00-15.00 and 15.00-7.00 h. It was found that pinealectomy significantly increased nocturnal oxygen consumption and rectal temperature. Pinealectomized hens consumed considerably more feed during the day, particularly in the afternoon and at night. These results show that pinealectomy in adult hens modifies circadian metabolic rate and feed intake.
\end{abstract}

KEY WORDS: hens, pinealectomy, oxygen consumption, rectal temperature, food intake

\section{INTRODUCTION}

Several physiological processes in birds change according to a set rhythm, synchronized with changes in lighting under standard maintenance conditions. Circadian patterns have been found for feed intake (Savory, 1980; Buyse et al., 1993), metabolic rate (Mac Leod et al., 1980; Mac Leod and Jewitt, 1984) and rectal temperature (Kadano and Besch, 1978; John and George, 1984). The 
pineal gland mediates the effects of light on an organism, and its hormone, melatonin, has several important physiological functions. It has been found that administering large doses of melatonin decreases feed consumption by chicks and induces sleep (Bermudez et al., 1983). Melatonin infusions also restore sleep suppressed in pigeons exposed to continuous light (Philips and Berger et al., 1992). Since it was found that pinealectomy significantly increases feed consumption in young cockerels (Injidi and Fobres, 1983), an experiment was undertaken to determine the effect of pinealectomy on oxygen consumption, rectal temperature and feed consumption in adult hens.

\section{MATERIAL AND METHODS}

The experiment was carried out on 15 Leghorn hens aged 16 months, with an average body weight of $2 \mathrm{~kg}$, that were in their first laying period. The birds were raised in cages and fed DJ mixture* to appetite with free access to water. The photoperiod in the room was $14 \mathrm{~h}$ of light and $10 \mathrm{~h}$ of darkness (light from 7.00 to $21.00 \mathrm{~h}$ ). The birds were divided into three groups. The control group was not subjected to any procedure, the second control group underwent a mock operation, while the experimental group underwent pinealectomy. The procedures were carried out under general anesthesia, induced by iv. administration of xylazine at a dose of $2 \mathrm{mg} / \mathrm{kg}$ body weight, supplemented by ketamine injection. The completeness of pineal resection was assessed histologically and anatomically after sacrificing the hens.

After the wound healed, oxygen consumption and rectal temperature were measured for 10 days during the light $(10.00-15.00 \mathrm{~h})$ and dark $(22.00-3.00 \mathrm{~h})$ phases. The light cycle in the measuring chamber was adjusted to the lighting conditions in the room. The hens did not fast before the measurements were made. Oxygen consumption was measured using a universal MG-4 type (Kipp-Zonen) diaferometer. Following weighing, the birds were placed individually in the measuring chamber, and after $30 \mathrm{~min}$ of adaptation, oxygen consumption was measured for $1 \mathrm{~h}$. The air temperature in the chamber was $20^{\circ} \mathrm{C}$. After the determination, the rectal temperature was measured in the cloaca at a depth of $4 \mathrm{~cm}$ with a thermistor thermometer (PG 102). During the 10-day period of the experiment, feed consumption between 7.00-15.00 and 15.00-7.00 h was monitored.

The obtained results were subjected to variance analysis; the significance of differences was assessed by the Duncan test.

\footnotetext{
* Commercial mixture, containcd $10.9 \mathrm{MJ}$ EM and $16 \% \mathrm{CP} / \mathrm{kg}$
} 


\section{RESULTS AND DISCUSSION}

The metabolic rate of birds is characterized, among others, by a circadian rhythm. Heat production in adult hens is highest during the day and drops to about $60-67 \%$ of this value at night (Mac Leod et al., 1980; Mac Leod and Jewitt, 1984).

In our study, diurnal oxygen consumption (Figure 1) of control group hens was $0.762 \pm 0.031 \mathrm{~cm}^{3} \mathrm{O}_{2} / \mathrm{h} / \mathrm{g}$ body weight and $0.66 \pm 0.12 \mathrm{~cm}^{3} \mathrm{O}_{2} / \mathrm{h} / \mathrm{g}$ at night. This difference was significant $(\mathrm{P} \leqslant 0.05)$. In the group of hens that underwent a mock operation, without resection of the pineal gland, diurnal oxygen consumption equaled $0.782 \pm 0.052 \mathrm{~cm}^{3} \mathrm{O}_{2} / \mathrm{h} / \mathrm{g}$ and $0.626 \pm 0.023 \mathrm{~cm}^{3} \mathrm{O}_{2} / \mathrm{h} / \mathrm{g}$ at night. These differences were also significant $(\mathrm{P} \leqslant 0.05)$. Diurnal oxygen consumption in pinealectomized hens was $0.800 \pm 0.035 \mathrm{~cm}^{3} \mathrm{O}_{2} / \mathrm{h} / \mathrm{g}$ and was only slightly higher than in the control groups, while in contrast with the controls, nocturnal consumption only slightly decreased: $0.767 \pm 0.045 \mathrm{~cm}^{3} \mathrm{O}_{2} / \mathrm{h} / \mathrm{g}$.

Under normal conditions, the plasma melatonin level in hens is low during the day and increases 4-5 fold at night (Liou et al., 1987). It can be presumed that the high level of this hormone during the dark period is related to the decline in the metabolic rate occurring at this time. This conclusion is supported by the results of Bermudez et al. (1983) who showed that injections of melatonin significantly decrease oxygen consumption in young cockerels. In the present experiment, we did not measure the plasma melatonin level in hens, but the literature data indicate that pinealectomy completely destroys the circadian rhythm of plasma melatonin levels (Pelham, 1975; Cogburn et al., 1987). The lack of a night-time

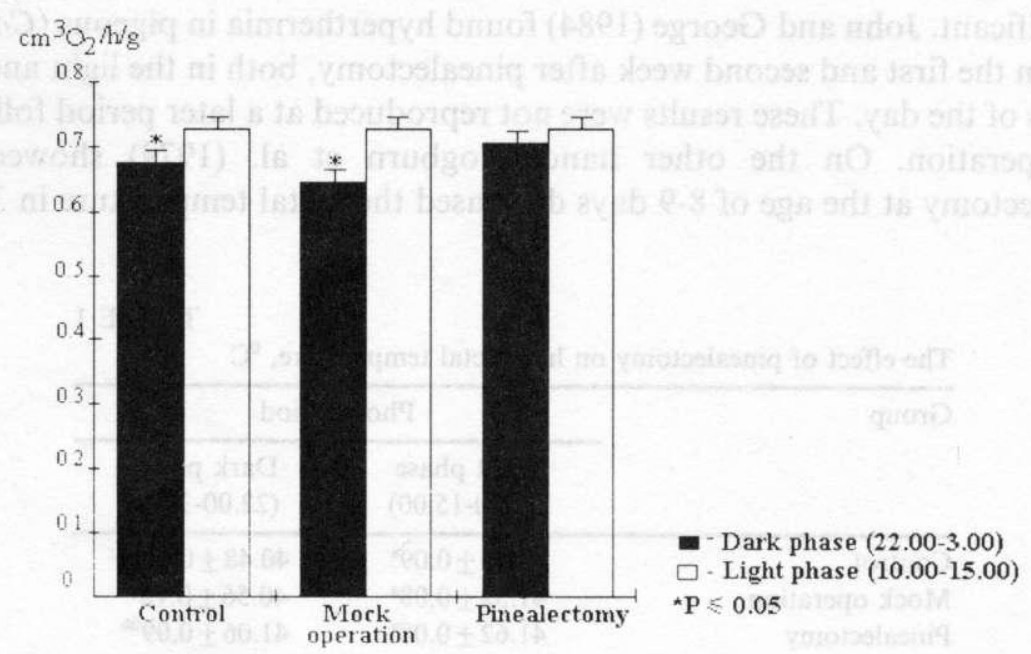

Figure 1. The effect of pinealectomy on oxygen consumption in hens 
rise in melatonin in the blood may explain why no significant differences in oxygen consumption were found in the pinealectomized group during the photocycle.

Changes in the metabolic rate of pinealectomized hens were reflected in their body temperature. The rectal temperature of hens (Table 1) during the light period in the control groups ranged, on average, from 41.52 to $41.56^{\circ} \mathrm{C}$, and was somewhat higher in the experimental group, $41.62^{\circ} \mathrm{C}$. These differences was not, however, significant $(P \geqslant 0.05)$, but the nocturnal decline was significant $(\mathrm{P} \leqslant 0.01)$. In the control group, the average daily variations in the rectal temperature equaled 1.08 and $0.96^{\circ} \mathrm{C}$, while in the experimental group, $0.56^{\circ} \mathrm{C}$.

Similar circadian changes in rectal temperatures in birds were observed by Woodard and Mather (1964). In studies carried out on adult roosters, Kadono and Besch (1978) showed that, among others, the rectal temperature of birds maintained at ambient temperatures $\left(23^{\prime \prime} \mathrm{C}\right)$ and photoperiod of $12 \mathrm{~L}: 12 \mathrm{D}$ (light during $7.00-18.00)$ reached a peak value $\left(41.7-41.9^{\circ} \mathrm{C}\right)$ between $13.00-15.00$, while the lowest $\left(41.0-41.1^{\circ} \mathrm{C}\right)$ between $23.00-3.00 \mathrm{~h}$. Daily temperature fluctuation equaled $0.9^{\circ} \mathrm{C}$ and was similar to that found in the control group of hens in our experiment.

The role of the pineal gland in regulating the circadian rhythm of bird body temperature has been the subject of many studies, which have not, however, provided unequivocal results. Binkely et al. (1971) showed that pinealectomy in the common sparrow (Passer domesticus) suppresses the circadian rhythm of rectal temperature under conditions of constant darkness. In the present study, the nocturnal rectal temperature of pinealectomized hens was significantly higher than in control birds, while the diurnal differences were slight and insignificant. John and George (1984) found hyperthermia in pigeons (Columba livia) in the first and second week after pinealectomy, both in the light and dark phases of the day. These results were not reproduced at a later period following the operation. On the other hand, Cogburn et al. (1979) showed that pinealectomy at the age of 8-9 days decreased the rectal temperature in 3-week

TABLE 1

The effect of pinealectomy on hen rectal temperature, ${ }^{0} \mathrm{C}$

\begin{tabular}{lcc}
\hline Group & \multicolumn{2}{c}{ Photoperiod } \\
\cline { 2 - 3 } & Light phase & Dark phase \\
& $(10.00-15.00)$ & $(22.00-3.00)$ \\
\hline Control & $41.56 \pm 0.09^{\mathrm{a}}$ & $40.48 \pm 0.12^{\mathrm{Aa}}$ \\
Mock operation & $41.52 \pm 0.08^{\mathrm{a}}$ & $40.56 \pm 0.12^{\mathrm{a}}$ \\
Pinealectomy & $41.62 \pm 0.08^{\mathrm{a}}$ & $41.06 \pm 0.09^{\mathrm{Bb}}$ \\
\hline
\end{tabular}

a. $\mathrm{b}-\mathrm{P} \leqslant 0.05 ; \mathrm{AB}-\mathrm{P} \leqslant 0.01$ 
TABLE 2

The effect of pinealectomy on feed consumption of hens during the day, $g /$ hen

\begin{tabular}{lccc}
\hline Group & \multicolumn{3}{c}{ Time of day, h } \\
\cline { 2 - 4 } & $7.00-15.00$ & $15.00-7.00$ & $24 \mathrm{~h}$ \\
\hline Controls + mock operation & $60.3 \pm 6.97^{\mathrm{A}}$ & $82.3 \pm 2.84^{\mathrm{A}}$ & $142.6 \pm 8.49^{\mathrm{A}}$ \\
Pinealectomized & $85.3 \pm 9.26^{\mathrm{h}}$ & $118.3 \pm 9.31^{\mathrm{B}}$ & $204.2 \pm 12.13^{\mathrm{B}}$ \\
\hline
\end{tabular}

$a, b-P \leqslant 0.05 ; A B-P \leqslant 0.01$

cockerels by $0.5^{\circ} \mathrm{C}$ during the light period and by $0.6^{\circ} \mathrm{C}$ in the dark phase of the day. There were no significant differences found, however, in the rectal temperatures of 8-week pinealectomized cockerels maintained at a temperature of $23^{\circ} \mathrm{C}$ (Cogburn and Harrison, 1980), while the lower body temperature of these birds when the surroundings has a temperature of $37^{\circ} \mathrm{C}$ illustrates, according to these authors, the interrelationship between pinealectomy and the ambient temperature.

The differences in metabolic rate and rectal temperature in the studied group of birds could also have been the result of the degree of filling of the digestive tract. Analysis of feed consumption (Table 2) showed that the pinealectomized hens ate $29.5 \%$ more feed between $7.00-15.00$ and $43.9 \%$ more during $15.00-7.00$ than the control groups. Together, over the entire $24-\mathrm{h}$ period the experimental hens consumed $204.2 \mathrm{~g} /$ hen feed, while the control hens, $142.6 \mathrm{~g} / \mathrm{hen}(\mathrm{P} \leqslant 0.01)$.

Adult hens maintained under a standard photoperiod usually do not eat at night if the dark period does not exceed $12 \mathrm{~h}$; feeding is almost entirely limited to daylight hours, and is more intense in the morning and late afternoon.

In our study, the experimental hens consumed more feed in the afternoon and at night in comparison with the controls, which suggests that pinealectomy increases feed intake, particularly at night. This hypothesis is borne out by the results of Injidi and Fobres (1983) who found that pinealectomized cockerels fed during complete darkness, in contrast with control birds. On the other hand, melatonin injections reduce feed intake and cause sleep (Bermudez et al., 1983; Injidi and Fobres, 1983).

The results of this study show that pinealectomy modifies the circadian feeding rhythm, oxygen consumption and rectal temperature of adult hens.

\section{ACKNOWLEDGMENT}

The authors would like to thank Prof. E. Wierzchos from the Agricultural University in Kraków for valuable advice and help in the pinealectomy of the hens. 


\section{REFERENCES}

Bermudez F.F., Forbes J.M., Injidi M.H., 1983. Involvement of melatonin and thyroid hormones in the control of sleep, food intake and energy metabolism in the domestic fowl. J.Physiol. 337, 19-27

Binkley S., Kluth E., Menaker M., 1971. Pineal function in Sparrows: Circadian rhytms and body temperature. Science 174, 311-314

Buyse J., Adelsohn D.S., Decuypere E., Scanes C.G., 1993. Diurnal-nocturnal changes in food intake, gut storage of ingesta, food transit time and metabolism in growing broiler chickens: a model for temporal control of energy balance. Brit. Poultry Sci. 34,699-709

Cogburn L.A., Harrison P.C., Balsbaugh R.K., 1979. Temperature preferendum of pincalectomized cockerels during their light-dark cycle. Proc. Soc. Exp. Biol. Med. 161, 425-429

Cogburn L.A., Harrison P.C., 1980. Adrenal, thyroid, and rectal temperature responses of pinealectomized cockerels to different ambient temperatures. Poultry Sci. 59, 1132-1141

Cogburn L.A., Wilson-Placentra S., Letcher L.R., 1987. Influence of pinealectomy on plasma and extrapineal melatonin thythms in young chickens (Gallus domesticus). Gen. Comp. Encocrinol. $68,343-356$

Injidi M.H., Fobres J.M., 1983. Growth and food intake of intact and pinealectomised chickens treated with melatonin and triiodothyronine. Brit. Poultry Sci. 24, 463-469

John T.M., George J.C., 1984. Diurnal thermal response to pinealectomy and photoperiod in the pigeon. J. interdiscipl. Cycle Res. 15, 57-67

Kadono H., Besch E.L., 1978. Telemetry measured body temperature of domestic fowl at various ambient temperatures. Poultry Sci. 57, 1075-1084

Liou S.S., Cogburn L.A.. Biellier H.V., 1987. Photoperiodic regulation of plasma melatonin levels in the laying chicken (Gallus domesticus). Gen.Comp. Endocrinol. 67, 221-226

MacLeod M.G., Tullett S.G., Jewitt T.R., 1980. Circadian variation in the metabolic rate of growing chickens and laying hens of a broiler strain. Brit. Poutry Sci. 21,155-159

MacLeod M.G., Jewitt T.R., 1984. Circadian variation in the heat production rate of the domestic fowl Gallus domesticus: effects of limiting feeding to a single daily meal. Comp. Biochem. Physiol. 78A, 687-690

Phillips N.H., Berger R.J., 1992. Melatonin infusionsrestore sleep suppressed by continuous bright light in pigeons. Neuroscience Letters, 145, 217-220

Savory C.J., 1980. Diurnal feeding patterns in the domestic fowl: a review. Appl. Anim. Ethol. 6, $71-82$

Pelham R.W.,1975. A scrum melatonin rhytm in chickens and its abolition by pinealectomy. Endocrinology 96, 543-546

Woodard A.E., Mather F.B., 1964. Effect of photoperiod on cyclic patterns of body temperature in the quail. Nature 203, 422-423

\section{STRESZCZENIE}

\section{Wplyw usunięcia szyszynki na zużycie tlenu i temperaturę rektalną u dojrzałych kur}

Badania przeprowadzono na 15 kurach rasy Leghorn w wieku 16 miesięcy odchowywanych w klatkach w standardowych warunkach żywienia i oświetlenia 14L:10D (światlo od 7.00 do 21.00 godz.). Grupę kontrolną stanowiły kury nie poddane żadnemu zabiegowi, w drugiej grupic 
kontrolnej wykonano zabieg operacyjny bez usuwania szyszynki, natomiast w grupie doświadczalnej szyszynkę usunięto. Wykonano pomiary zużycia tlenu i temperatury rektalnej w fazie świetlnej dnia (godz. 10.00-15.00) oraz w fazie ciemnej (godz. 22.00-3.00), oraz kontrolowano pobieranie paszy w godz. 7.00-15.00 i 15.00-7.00.

Stwierdzono, że pinealektomia istotnie zwiększa zużycie tlenu i temperaturę rektalną kur w porze nocnej. Kury pozbawione szyszynki pobierały istotnie więcej paszy w ciągu doby, szczególnie po południu i nocą.

Uzyskane wyniki wskazują, że pinealektomia u dorosłych kur modyfkuje okołodobowy rytm tempa metabolizmu i pobierania pokarmu. 